\title{
OSTI
}

\section{Surface Area Considerations for Corroding N Reactor Fuel}

A. B. Johnson, Jr.

A. L. Pitner

June 1996

Prepared for the U.S. Department of Energy under Contract DE-AC06-76RLO 1830

Pacific Northwest National Laboratory Operated for the U.S. Department of Energy by Battelle

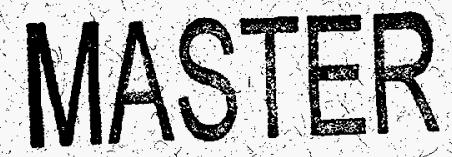




\title{
DISCLAIMER
}

This report was prepared as an account of work sponsored by an agency of the United States Government. Neither the United States Government nor any agency thereof, nor Battelle Memorial Institute, nor any of their employees, makes any warranty, express or implied, or assumes any legal liability or responsibility for the accuracy, completeness, or usefulness of any information, apparatus, product, or process dísclosed, or represents that its use would not infringe privately owned rights. Reference herein to any specific commercial product, process, or service by trade name, trademark, manufacturer, or otherwise does not necessarily constitute or imply its endorsement, recommendation, or favoring by the United States Government of any agency thereof, or Battelle Memorial Institute. The views and opinions of authors expressed herein do not nécessarily state or reflect those of the United States Government or any agency thereof.

\author{
PACIFIC NORTHWEST NATIONAL LABORATORY \\ operated by \\ BATTELLE \\ for the \\ UNITED STATES DEPARTMENT OF ENERGY \\ under Contract DE-AC06-76RLO 1830
}

Printed in the United States of America

Available to DOE and DOE contractors from the

Office of Scientific and Technical Information, P.O Box 62, Oak Ridge, TN 37831;

prices available from (615) $576-8401$.

Available to the public from the National Technical information Service, U.S. Department of Commerce, 5285 Port Royal Rd, Springfield, VA 22161

This document was printed on recycled paper 


\title{
SURFACE AREA CONSIDERATIONS FOR
} CORRODING N REACTOR FUEL

\author{
A.B. Johnson, Jr. \\ A.L. Pitner ${ }^{1}$
}

June 1996

Prepared for the U.S. Department of Energy under Contract DE-AC06-76RLO 1830

Pacific Northwest National Laboratory

Richland, Washington 99352

${ }^{1}$ Westinghouse Hanford Company 



\section{SUMMARY}

The $N$ Reactor fuel is corroding at sites where the Zircaloy cladding was damaged when the fuel was discharged from the reactor. Corroding areas are clearly visible on the fuel stored in open cans in the $\mathrm{K}$ East Basin. There is a need to estimate the area of the corroding uranium to analyze aspects of fuel behavior as it is transitioned from current wet storage to dry storage. In this report, the factors that contribute to "true" surface area are analyzed in terms of what is currently known about the $\mathrm{N}$ Reactor fuel. Using observations from a visual examinations of the fuel in the K East wet storage facility, a value for the corroding geometric area is estimated. Based on observations of corroding uranium and surface roughness values for other metals, a surface roughness factor is also estimated and applied to the corroding $\mathrm{K}$ East fuel to provide an estimated "true" surface area. While the estimated area may be modified as additional data become available from fuel characterization studies, the estimate provides a basis to assess effects of exposed uranium metal surfaces on fuel behavior in operations involved in transitioning from wet to dry storage, during shipment and staging, conditioning, and dry interim storage.

The factors that need consideration for accurately determining the $\mathrm{N}$ Reactor fuel true surface area involve the following parameters and phenomena:

- geometric area

- radiation-induced porosity

- microcracks in the uranium metal fuel

- roughness factors

- other phenomena, e.g., intergranular corrosion, if present.

Also, the current strategy is to place fuel rubble into cans that will be inserted into the multicanister overpacks (MCOs) along with the fuel canisters. Therefore, the surface area of the rubble also has become an issue.

How the surface area factors indicated above apply to the N Reactor fuel is not yet characterized by direct examination of the fuel. However, the best current understanding of the factors as they apply to the $\mathbf{N}$ Reactor fuel is addressed in this report. 


\section{Surface Areas of Elements Corroding in K East Basin}

The estimated geometric area, based on video examination of the fuel in the $\mathrm{K}$ East (KE) Basin, is $\sim 5 \times 10^{5} \mathrm{~cm}^{2}$, subject to assumptions. The dominant surface area contribution comes from the "split cladding" fuel category, based on the assumptions. A more accurate value for the true area of the corroding uranium in $\mathrm{K}$ East could be derived from ${ }^{137} \mathrm{Cs}$ release data if the relevant rate constant for corrosion of $\mathrm{N}$ Reactor uranium metal could be measured under $\mathrm{K}$ East Basin conditions. Otherwise, the alternate approach is to apply the most appropriate rate constant from the literature. Use of a literature value for the rate constant resulted in an estimated "true" surface area of $9 \times 10^{6} \mathrm{~cm}^{2}$. The inferred roughness factor is 18 , obtained by dividing the "true" surface area by the geometric area. This value is considered to be high, based on an analysis summarized in a later section, suggesting that a value of 5 is more credible. Multiplying the estimated geometric area by 5 results in an estimated "true" surface area of $2.5 \times 10^{6} \mathrm{~cm}_{2}$ for the fuel corroding in $\mathrm{K}$ East. This estimated area may be subject to revisions as data emerges from the fuel characterization investigations and from additional visual inspections of fuel in the $\mathrm{K}$ East Basin.

An ongoing analysis (Cooper and Johnson) is examining the credibility of a published value for uranium corrosion in oxygenated water as a basis for estimating the area of the corroding K East fuel.

\section{Radiation-Induced Porosity}

Radiation-induced porosity is judged to have a minor effect on true surface area, because burnups on the failed N Reactor fuel are generally $3000 \mathrm{MWd} / \mathrm{MT}$ or below. Even on $\mathrm{N}$ Reactor fuel with the highest estimated burnups ( $7000 \mathrm{MWd} / \mathrm{MT})$, if porosity is significant, it will result in a narrow band of pits near the metal surfaces for fuel corroding from the ends, with most of the metal cross section substantially unaffected.

\section{Effects of Microcracks}

Reactions in tight microcracks in the metal are expected to be diffusion-limited; in that case, the cracks would not contribute substantially to true surface area. If the metal is segmented, the area increase could be significant when the segmented metal is exposed to reactants. Microcracks were not observed when a damaged $\mathrm{K}$ West fuel element was examined metallographically in a hot cell at a location approximately $12 \mathrm{in} .(30 \mathrm{~cm})$ from the damaged end. Cracks also were not observed by Swanson on elements that had survived discharge without breaching the cladding. On the other hand, Swanson (1988) reported that after the cladding was dissolved from a damaged $\mathrm{N}$ Reactor fuel element, a jumble of broken pieces was observed, rather than a solid cylinder of uranium. The element had corroded 12 years in water after reactor discharge. Swanson attributed the segmentation to reaction of the partially degraded uranium cylinder with the decladding solution $\left(5 \mathrm{M} \mathrm{NH} \mathrm{N}_{4} \mathrm{~F}+0.45 \mathrm{M} \mathrm{NH}_{4} \mathrm{NO}_{3}\right)$. The reaction was proposed to involve hydrides that developed in uranium grain boundries. 
Segmentation resulted in a high surface area that lead to increased reaction with the processing solution. However, for a clad element corroding from an end, it seems possible that segmented metal will not be generated and exposed at substantial rates. It also is not clear whether an element with cladding damage on the sides will be subject to segmentation from aqueous corrosion if the metal cylinder does not have penetrating cracks.

\section{Surface Roughness Factors}

Surface roughness factors in the corroding areas are estimated to be $\sim 5$, based on the following evidence:

- macro roughness factors determined from cross sections of corroding uranium (1.3 to 2.4) (does not include contributions from micron-sized micro roughness)

- estimates by Swanson that roughness factors for corroding irradiated uranium metal corroding in nitric acid were 2.4 to 4

- roughness factor measurements on other metals (Appendix C), in the range of 1.1 to 4.3, depending on how the surface was treated.

- geometric calculations suggesting that micron-sized asperities result in a roughness factor of at least 2 , and possibly higher, depending on the surface configuration on a micro scale.

Thus, the roughness factor of 18 , indicated earlier, based on ${ }^{137} \mathrm{Cs}$ release data in $\mathrm{K}$ East Basin and a literature value for the corrosion rate constant, seems high, compared to the surface roughness data cited above. A more relevant basis to establish true surface area for the corroding fuel in $\mathrm{K}$ East would need to involve determination of a corrosion rate constant on $\mathrm{N}$ Reactor uranium under conditions in the basin.

\section{Intergranular Corrosion}

Metallography on unirradiated uranium metal fuel that corroded in high-conductivity basin water at the Savannah River Site, indicates intergranular attack, contributing to enhanced surface area. Whether the attack on the $\mathrm{N}$ Reactor fuel is intergranular remains to be determined in ongoing fuel examinations. 


\section{Fuel Rubble ${ }^{1}$}

The current concept is to place fuel rubble into canisters that will be positioned inside the MCOs, along with the fuel elements. The intent to include the rubble in the MCOs imposes an additional surface area consideration. Rubble necessarily involves exposed uranium with some or all of the surface corroding. The following sources of fuel rubble have been identified for the fuel inventory in $\mathrm{K}$ East:

- fuel rubble from the 1980 's Segregation Camapign, estimated to be approximately 10 canisters, with fuel segments less than 6 in. $(15 \mathrm{~cm})$

- fuel rubble from the 1992/93 cleanup of the loading pit area (2 canisters, No. 3910 and 3911)

- fuel rubble estimated from visual inspection of the $\mathrm{K}$ East fuel canisters, including broken elements and loose end caps; the corroding area is estimated to be $5 \times 10^{4} \mathrm{~cm}^{2}$

- fuel rubble generated during the upcoming fuel handling operations; on one hand, the rubble inventory may be mitigated because in the Segregation Campaign about one half of the elements were disassembled, involving relatively vigorous handling. On the other hand, there has been more than a decade of additional corrosion that may make some fuel more vulnerable to breakage. The current characterization campaign involving $\mathrm{K}$ East fuel may provide a more quantitative perspective on fuel rubble expectations. Until those data are available, there does not seem to be a more reasonable assumption than to regard the rubble inventories in the 1980s campaign and in the upcoming campaign as equivalent.

There are also 12 canisters in K West that are designated "fuel chip" canisters and contain fuel segments from fuel handling operations at the $\mathrm{N}$ Reactor. The cans each contain less than $180 \mathrm{lb}(82 \mathrm{~kg})$ of uranium fuel on a dry weight basis, but the records do not indicated information regarding fuel segment sizes.

To estimate the area of the corroding rubble, two approaches can be considered: a theoretical approach, assuming a distribution of rubble particle sizes; or an empirical approach, based on the underwater video inspections and assumptions regarding the exposed areas in the scrap

\footnotetext{
${ }^{1}$ It is necessary to understand terms used to differentiate fuel segments and other metallic pieces that reside in the $\mathrm{K}$ Basins. Fuel segments have been referred to as chips, scrap, and rubble. Nonfuel materials, e.g., Zircaloy fuel spacers ("buggy springs") and loose spacers clad with carbon steel, are generally referred to as debris, although the term nonfuel rubble has also been used. A range of interpretations regarding fuel particle sizes that constitute rubble are summarized in the report.
} 
canisters. The rubble inventory most difficult to estimate is that to be generated in the upcoming fuel handling campaign. The fuel category that seems most likely to contribute fuel segments and particles is that designated "split cladding." It seems useful to inspect "split cladding" elements to determine the degree that the remaining fuel is segmented and to gain insight to the area of corroding metal. Discussions with staff involved in the Segregation Campaign indicate that fuel segments were not prominent as the fuel was handled on the sorting table.

The basis to estimate the area of corroding rubble is being addressed in an ongoing assessment by Cooper and Johnson.

\section{Conclusions}

1. Based on interpretation of underwater video inspection of uranium fuel elements in the $K$ East canisters, a corroding geometric area of $5 \times 10^{5} \mathrm{~cm}^{2}$ was estimated. This does not include the area of fuel rubble, which is addressed below.

2. The dominant fuel category that contributes to the estimated corroding area is "split cladding", which has the least observable area factors. Therefore, characterization that would be most productive in improving the basis for estimating the corroding area would be inspection of several elements in the "split cladding" category.

3. Based on estimated macro roughness factors for corroding uranium, roughness factor estimates by Swanson for uranium corroding in nitric acid, and general values of roughness factors for other metals, a value of 5 is recommended for the corroding uranium, subject to modification as results of ongoing $\mathrm{N}$ Reactor fuel characterization data become available.

4. Applying a roughness factor of 5 to the geometric area of the corroding nonrubble fuel inventory results in an estimated "true" corroding area of $2.5 \times 10^{6} \mathrm{~cm}^{2}$.

5. The following geometric areas are estimated for the fuel rubble currently stored in the $\mathrm{K}$ East Basin:

- visually evident broken fuel and loose end caps: $4 \times 10^{4} \mathrm{~cm}^{2}$

- rubble in two cans from the 1992/93 loadout pit campaign: negligible area

- rubble in approximately 10 cans from the Segregation Campaign (described as fuel segments less than 6 in.): an area estimate will be made after the fuel rubble inventory has been better defined 
- rubble from the upcoming fuel handling campaign: assume an inventory similar to the Segregation Campaign. On one hand, rubble generation was enhanced in the Segregation Campaign by disassembly of about half of the elements; on the other hand, more than a decade of additional corrosion is likely to make the fuel more susceptilbe to breakage.

There are also 12 cans containing fuel rubble in the $\mathrm{K}$ West fuel inventory, but the records do not indicate the sizes of the fuel segments.

6. Contributions of other factors (microcracks, porosity, and intergranular attack) to $\mathrm{N}$ Reactor fuel surface area await results from fuel characterizations. Results from ongoing and future hot cell examinations are needed to improve perspectives on the surface area of corroding $\mathrm{N}$ Reactor fuel. An intergranular mechanism is known to be active on unirradiated uranium metal that corroded in relatively impure water in a Savannah River Site fuel storage pool. 


\section{CONTENTS}

Summary $\ldots \ldots \ldots \ldots \ldots \ldots \ldots \ldots \ldots \ldots \ldots \ldots \ldots \ldots \ldots \ldots \ldots$ iii

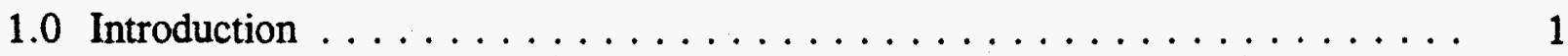

2.0 Surface to Volume Ratio Assuming Complete Decladding $\ldots \ldots \ldots \ldots$

3.0 Factors that Define True Surface Area of the Corroding N Reactor Fuel $\ldots . .5$

4.0 Fraction of Uranium Surface that is Currently Subject to Corrosion $\ldots \ldots \ldots 7$

4.1 Surface Area Estimated from Underwater Video Inspections of

$\mathrm{N}$ Reactor Fuel in the KE Basin . . . . . . . . . . . . . 7

4.2 Area Calculated from Uranium Metal Corrosion Rate in the KE Basin . . . 14

5.0 Characterization of Factors that Define True Surface Area of Corroding

N Reactor Fuel . . . . . . . . . . . . . . . . . . . . . . . . . 17

5.1 Porosity in Uranium Metal During Irradiation . . . . . . . . . . 17

5.2 Surface Area that May Arise form Microcracking of Uranium

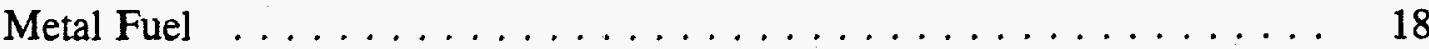

5.3 Roughness Factors for Corroding Uranium Metal Fuel . . . . . . . . . 18

5.4 Other Phenomena that Could Contribute to True Surface Area of Corroding $\mathrm{N}$ Reactor Fuel $\ldots \ldots \ldots \ldots \ldots \ldots \ldots$

6.0 Contributions of Fuel Rubble to Corroding Uranium Surface Area in MCOs . . . 23

6.1 Definition of Rubble $\ldots \ldots \ldots \ldots \ldots \ldots \ldots \ldots \ldots \ldots \ldots \ldots \ldots$

6.2 Observations from the Segregation Campaign Relevant to Rubble . . . . . . 24

6.3 Contributions to Rubble Based on Video Inspection of $\mathrm{KE}$

Basin Fuel . . . . . . . . . . . . . . . . . . 25

6.4 Perspectives on Types of Fuel Segments from Visual Inspection of Fuel in $\mathrm{KE}$ Basin . . . . . . . . . . . . . . . . . . . . 25 
6.5 Fuel Rubble Consideration in the K West Inventory . . . . . . . . . 29

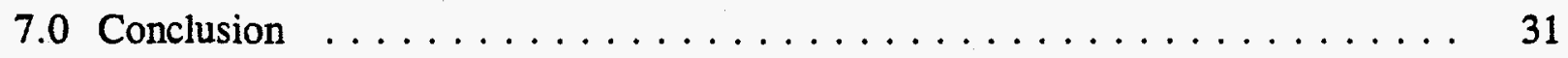

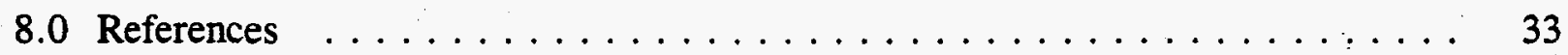

Appendix A - Estimate of Corrosion on N Fuel in the KE Basin . . . . . . . A.1

Appendix B - Summary of Data Needs to Resolve Uncertainties Regarding

Surface Area Factors for $\mathrm{N}$ Reactor Fuel $\ldots \ldots \ldots \ldots \ldots$ B.1

Appendix C - Surface Roughness Factors for Selected Metals and

Surface Conditions $\ldots \ldots \ldots \ldots \ldots \ldots \ldots \ldots \ldots \ldots$ C.1

\section{FIGURES}

1 N Reactor Fuel: Incipient Failure Category $\ldots \ldots \ldots \ldots \ldots$

$2 \quad$ N Reactor Fuel: Rupture Category $\ldots \ldots \ldots \ldots \ldots \ldots \ldots$

3 N Reactor Fuel: Loose End Cap Category $\ldots \ldots \ldots \ldots \ldots \ldots . \ldots \ldots$

4 N Reactor Fuel: Split Cladding Category $\ldots \ldots \ldots \ldots \ldots \ldots \ldots \ldots$

5 Four Typical Pit Types Found on Unirradiated Target, After Corrosion in a Fuel Storage Pool Over Five Years $\ldots \ldots \ldots \ldots . \ldots \ldots \ldots$

6 High Magnification of Corrosion on Unirradiated Mark 31 Uranium Target, Indicating Intergranular Attack $\ldots \ldots \ldots \ldots \ldots \ldots \ldots \ldots \ldots \ldots \ldots$

7 N Reactor Fuel: Broken Element $\ldots \ldots \ldots \ldots \ldots \ldots \ldots \ldots \ldots \ldots$

8 N Reactor Fuel: Element with Missing Section $\ldots \ldots \ldots \ldots$ 


\subsection{INTRODUCTION}

The surface area of exposed uranium metal is a key parameter in assessing the reaction characteristics during drying, transport, staging and storage of $\mathbf{N}$ Reactor fuel at the Hanford Site in Richland, Washington. The most relevant approach to quantify the true surface area for the corroding $\mathrm{N}$ Reactor fuel in the $\mathrm{K}$ East Basin would be derived from the steady state ${ }^{137} \mathrm{Cs}$ release rates and from a corrosion rate constant determined on fuel specimens under basin conditions. Lacking the relevant corrosion rate constant, two other approaches can be considered: application of a rate constant from the literature or estimation of the geometric corroding area from the systematic visual inspection of the $\mathrm{K}$ East Basin fuel inventory performed by Pitner (1995). Applying the later approach requires characterizing the elements of true surface area that need to be considered to facilitate estimation of an effective roughness factor for the corroding fuel.

A key concept is that any solid metal surface has asperities and possibly internal surfaces that define a true surface area that is larger than the geometric area. Experimental determinations of true metal surface areas are feasible (Johnson 1962). Gas absorption methods have been used to estimate true surface areas of unirradiated metals. Polarization capacitance has been applied to estimate metal surface roughness factors.

For irradiated metal fuel, the cost and schedule is not likely to accommodate generation of quantitative surface area data. However, the fuel examinations can provide important input to assess the factors that affect true surface area, including the geometry of the corroding area; whether porosity is evident; characteristics of microcracks, if evident; macroroughness of corroding areas; whether intergranular attack is evident; and whether metal segments are evident, particularly in the "split cladding" fuel category.

This assessment identifies the important factors in defining the true surface area of the corroding $\mathrm{N}$ Reactor fuel. The potential elements of enhanced surface area are addressed in the following sections. Estimates of the amount of fuel corrosion in the $\mathrm{K}$ East (KE) Basin are provided in Appendix A. A summary of uncertainties in the data base regarding corroding surface area for the N Reactor fuel is provided in Appendix B. Appendix C provides a summary of surface roughness factors for other metals as a function of surface treatment. 



\subsection{SURFACE TO VOLUME RATIO ASSUMING COMPLETE DECLADDING}

One approach to bound the area of a corroding element has been to assume that the entire surface of an element is available for reaction, i.e., that there is no Zircaloy cladding. The resulting surface to volume value is $220 \mathrm{~m}^{2} / \mathrm{m}^{3}$. This value does not include a factor for surface roughness. In this assessment we will investigate an alternative approach to estimate the true surface area by identifying and combining identifiable factors that define corroding areas on $\mathrm{N}$ Reactor elements that reside in the $\mathrm{KE}$ Basin. The incentive for the alternative approach is that the fully-declad case involves a highly conservative position. The alternative proposes to advance an estimated but more realistic value for the surface area of the uranium fuel corroding in the $\mathrm{K}$ East Basin. 



\subsection{FACTORS THAT DEFINE TRUE SURFACE AREA OF THE CORRODING N REACTOR FUEL}

Assessing the true surface area of corroding $\mathrm{N}$ Reactor fuel must include the following considerations:

1. What is the current geometric surface area of KE Basin fuel that is subject to corrosion?

2. During radiation, was metal porosity generated that will enhance the true area of corroding surfaces?

3. When the fuel was discharged, were microcracks formed in the relatively brittle metal fuel that will enhance the true area of the reacting surface?

4. What is the range of roughness factors that apply, due to asperities on the corroding surfaces?

5. Are other phenomena that could contribute to internal surface area, e.g., intergranular corrosion, occurring on the $\mathrm{N}$ Reactor fuel? 



\subsection{FRACTION OF URANIUM SURFACE THAT IS CURRENTLY SUBJECT TO CORROSION}

In this section, methods that have been applied to estimate the corroding area of the $\mathrm{N}$ Reactor fuel are summarized.

\subsection{Surface Area Estimated from Underwater Video Inspections of $\mathbf{N}$ Reactor Fuel in the KE Basin}

A recent underwater video inspection of the $\mathrm{N}$ Reactor fuel in KE Basin provides the most factual basis to assess the area of fuel corroding (Pitner 1995). Pitner estimated that $42 \%$ of the outer elements and $27 \%$ of the inner elements are corroding. This estimate includes the assumption that equal numbers of upper and lower ends of the fuel are corroding, except for split cladding; when split outer elements were replaced in canisters after the Segregation Campaign in the 1980s, they were oriented in the upright position, according to staff that participated.

\subsubsection{Categories of Failed N Fuel}

Photographs of N Reactor fuel corroding in the KE Basin indicate a range of corroding areas, characterized by Pitner into four categories (Pitner 1995):

- Incipient: involving areas where corrosion is barely evident

- Rupture: involving a clear break in the cladding, often with corrosion products extending from the cladding breach, but comprising areas that are less than the full cross section of an element

- Loose End Cap: involving a circumferential breach such that the end cap is loosely attached or is detached, generally appearing to comprise corrosion on the full cross section of an element

- Split Cladding: involving extensive corrosion that has caused splits in the Zircaloy cladding; the full extent of the exposed uranium areas is not observable, but seems to include exposed metal areas that are potentially much larger than a cross section.

\subsubsection{Approach and Assumptions}

A basis to estimate the corroding area of the uranium metal fuel in the KE Basin is derived from the data and observations obtained from underwater video observations on the fuel (Pitner 1995). 
The approach to an estimated corroding surface area involves the following assumptions:

1. A model that is based on a corroding area unit, defined as equal to the geometric cross sectional area of an element; area units are defined for outer and inner elements as follows:

- $\mathrm{A}_{\mathrm{UO}}=$ area unit of an outer element $=14 \mathrm{~cm}^{2}$

- $\mathrm{A}_{\mathrm{Ul}}=$ area unit of an inner element $=7.2 \mathrm{~cm}^{2}$

2. Number of corroding elements by categories that define the degree of degradation:

- Incipient: $\quad 1 / 2$ of the number indicated in Pitner's Table 2, based on uncertainty in identifying whether a cladding breach had occurred; the number is then doubled to account for the assumption that equal numbers of incipients are likely on the bottom ends of the elements, which are not currently observable

- Rupture: two times the number indicated in Pitner's Table 2, to account for expected damage on the lower ends of the elements

- Loose End Cap: two times the number indicated in Pitner's Table 2, to account for expected damage on the lower ends of the elements

- Split Cladding: discussion with staff involved in the Segregation Campaign indicates that elements with outers in advanced stages of degradation were replaced in canisters in the upright position, suggesting that the factor of two does not apply to elements in the Split Cladding category; there is currently no basis to assess whether advanced degradation has resulted in cases of Split Cladding on the lower ends of elements since the Segregation Campaign; however, fuel inspections are planned that will provide information regarding damage on the lower ends of the elements.

3. Distribution of Area Units among the four categories:

- Incipient: the corroding areas are generally barely discernible; the estimated fraction of the cross section that is corroding is $1 \%(0.01)$; see Figure 1 and Pitner Figure 20

- Rupture: the corroding areas are generally much smaller than a full geometric cross sectional area; the average area is estimated to be $25 \%$ $(0.25)$ of the Area Unit, $A_{U}$; see Figure 2 and Pitner Figures 21-24 


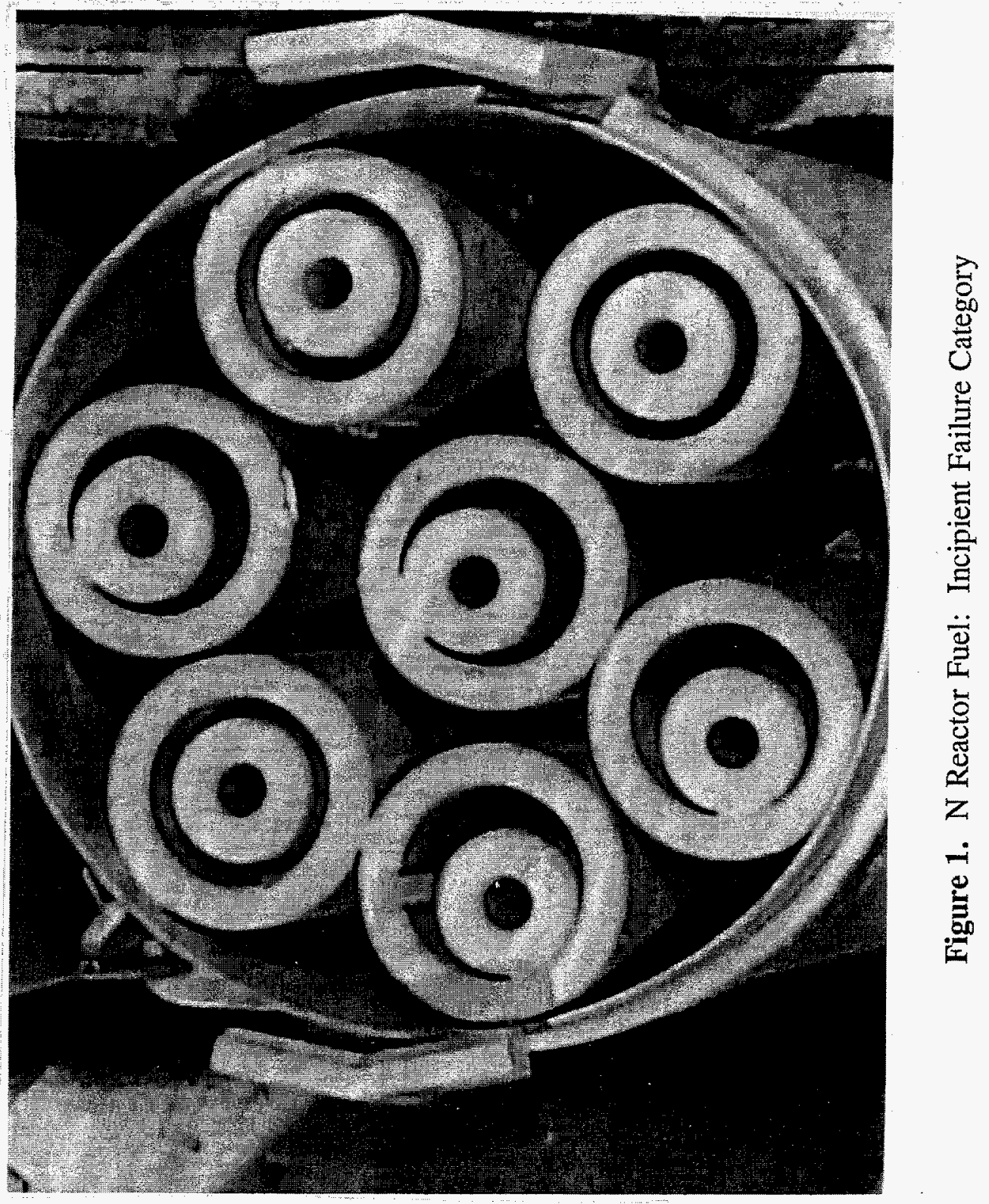




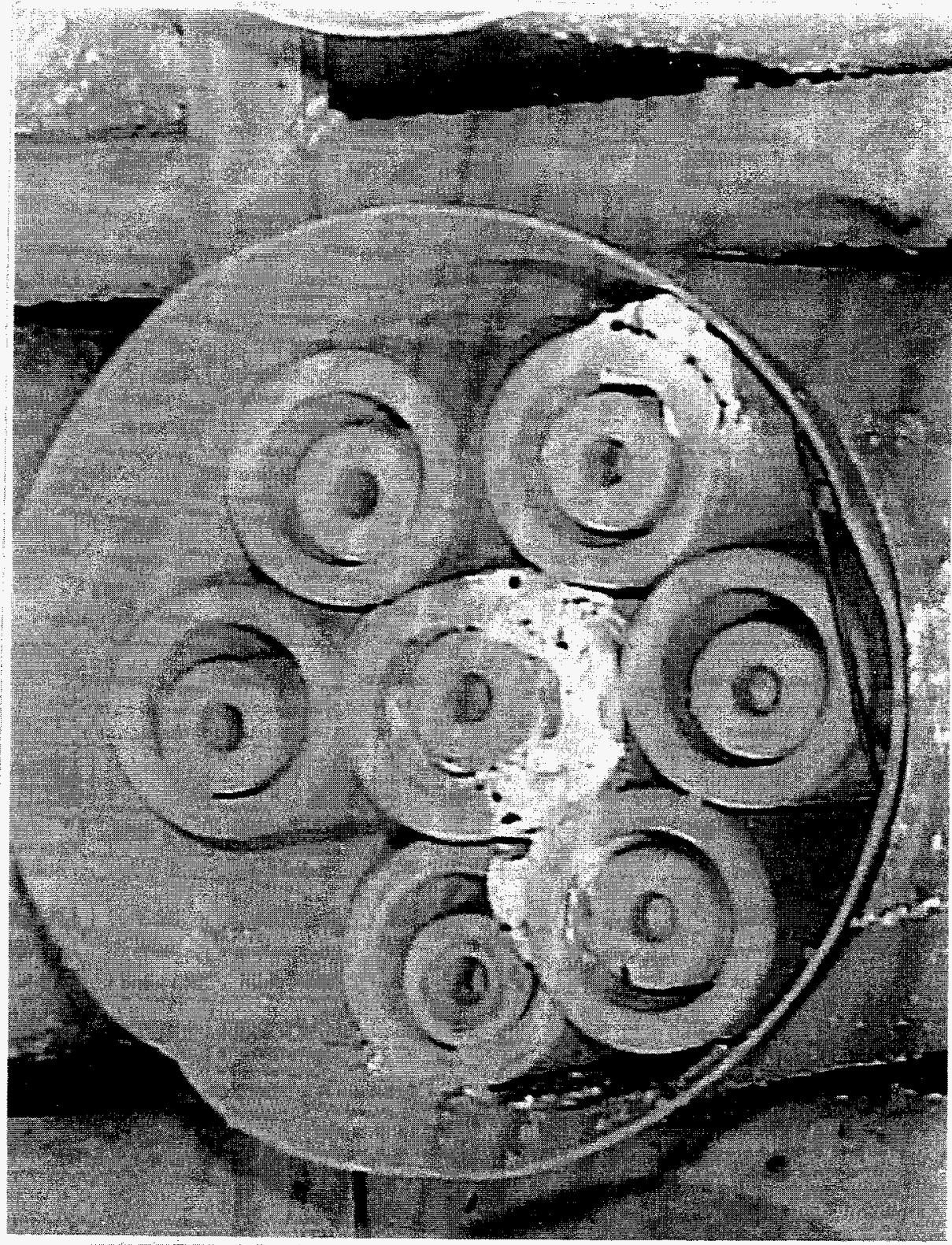

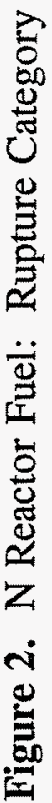


- Loose End Cap: once the corrosion area has matured, it appears to involve the full cross section of the element; the corroding areas are covered by corrosion products; the corroding area is assumed to be equal to the cross sectional area, i.e., to equal one Area Unit, $A_{U}=1$; see Figure 3 and Pitner Figures 25-27, 30; Johnson and Burke 1995, Figure 3-3; Swanson, Figures 3.6 and 3.8

- Split Cladding: based on discussion with Pitner, assume that 3 in. $(7.5 \mathrm{~cm})$ of the metal length is exposed by cladding splits; see Figure 4, Pitner Figures 33, 39, and 42; Swanson Figures 3.7 and 3.8, for examples of split cladding; the corresponding areas of exposed metal are

- outers: $17 x A_{U O}$

- inners: $14 \mathrm{xA}_{\mathrm{UI}}$.

\subsubsection{Results of KE Basin Corroding Fuel Area Estimate}

Table 1 summarizes the numbers of elements, corrected for the fact that only $70 \%$ of elements were observable in the inspection campaign (multiply number of observed elements by 1.43) and the assumption that there are equal numbers of failures of each type on the bottom ends of the elements (except for Split Cladding outers, which are assumed to have been oriented to the upright position while they were replaced into canisters after the Segregation Campaign).

From the total area factors for outer and inner elements in the table, the following total corroding areas are calculated:

- Outer elements: $\mathrm{A}_{\mathrm{UO}}=14 \mathrm{~cm}^{2}$

$$
30,000 \mathrm{~A}_{\mathrm{UO}} \times 14 \mathrm{~cm}^{2} / \mathrm{A}_{\mathrm{UO}}=4.2 \times 10^{5} \mathrm{~cm}^{2}
$$

- Inner elements: $\mathrm{A}_{\mathrm{UI}}=7.2 \mathrm{~cm}^{2}$

$$
5,000 \mathrm{~A}_{\mathrm{UI}} \times 7.2 \mathrm{~cm}^{2}=0.4 \times 10^{5} \mathrm{~cm}^{2}
$$

The total estimated corroding geometric surface area on $\mathrm{KE}$ Basin fuel elements, combining outers and inners, is $4.6 \times 10^{5} \mathrm{~cm}^{2}$, rounded to $5 \times 10^{5} \mathrm{~cm}^{2}$. 


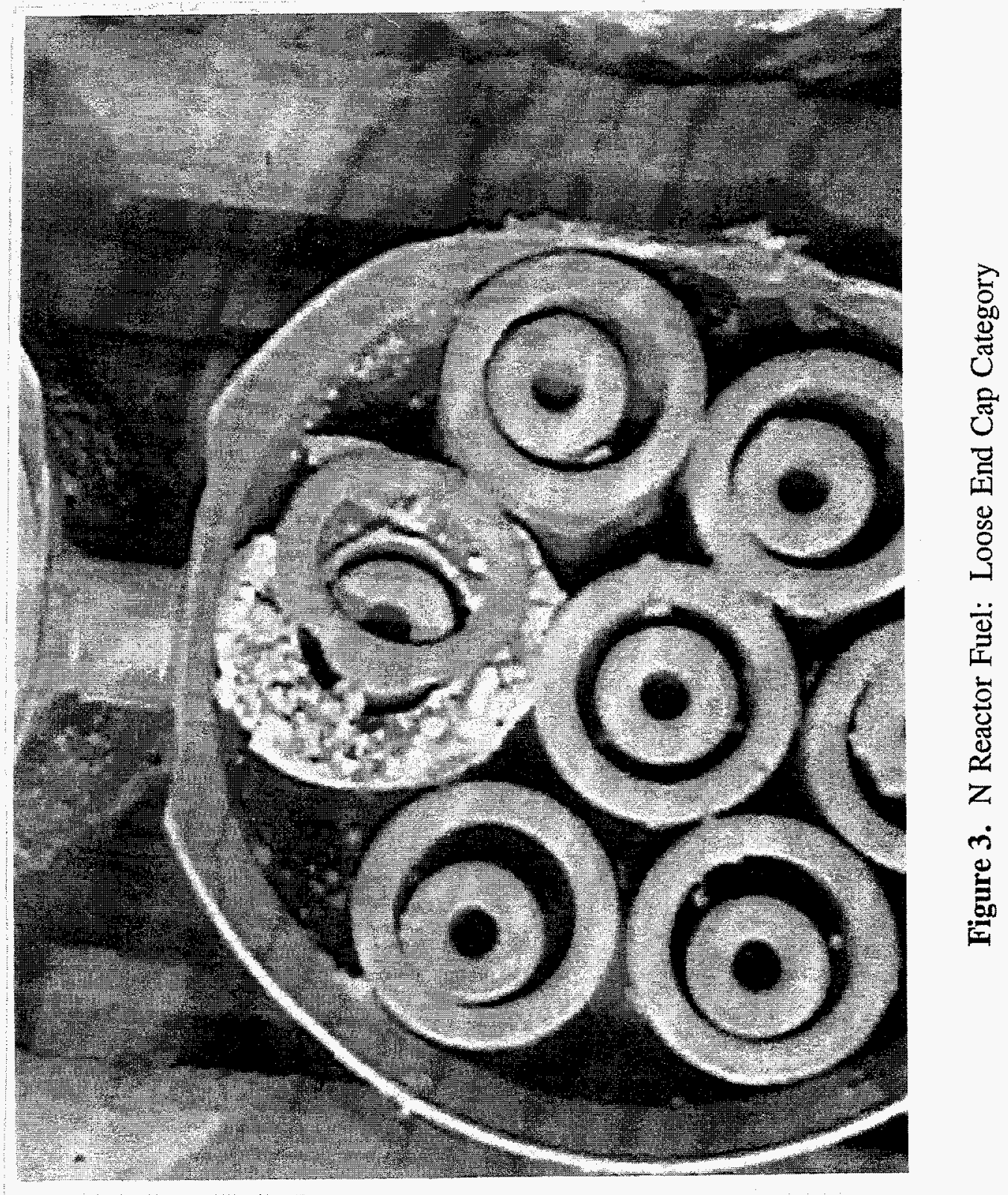




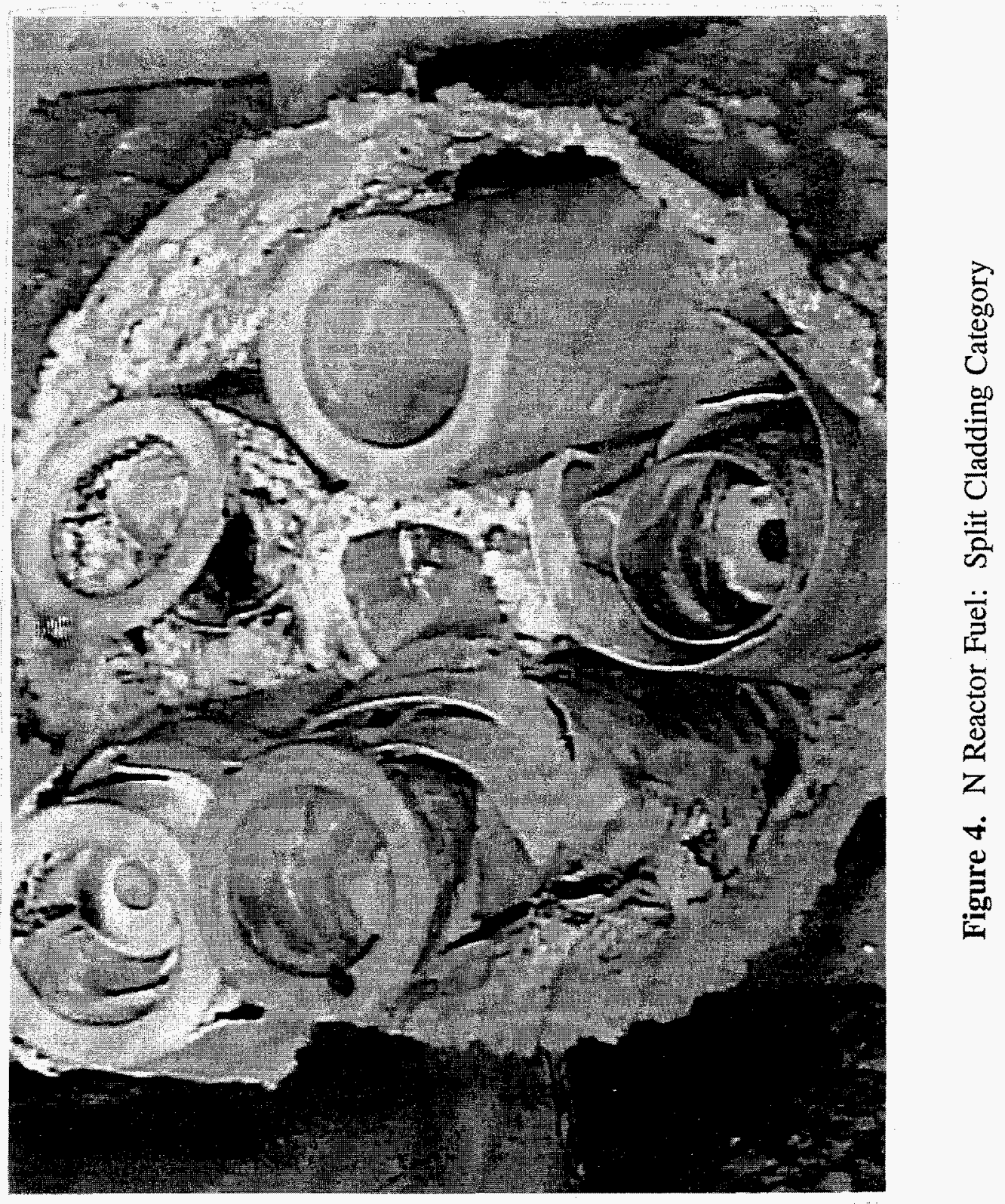


If all damaged inner and outer fuel elements in KE Basin were fully declad ${ }^{1}$, the exposed uranium metal area, including ID and OD surfaces, would be $60 \times 10^{6} \mathrm{~cm}^{2}$. The fraction of the total geometric uranium area (damaged elements only) that is currently subject to corrosion is

$$
5 \times 10^{5} / 60 \times 10^{6} \times 100 / 1=0.8 \% .
$$

It becomes evident from Table 1 that, subject to the assumptions, the area of uranium exposed by split cladding on outer elements is the dominant area factor. A more factual assessment would be possible if uncertainties indicated in Appendix B were resolved. The areas summarized above do not include estimates of surface roughness factors on the corroding surfaces, which are addressed in a later section.

\subsection{Area Calculated from Uranium Metal Corrosion Rate in the KE Basin}

An approach to estimate the "true" area of the corroding $\mathrm{N}$ Reactor fuel involves the relationship:

$$
\operatorname{UCR}(g \mathrm{~g} / \mathrm{d})=\mathrm{K}^{*} \mathrm{~A}_{\mathrm{T}}=\mathrm{K}^{*} \mathrm{R} \mathrm{A}_{\mathrm{G}}
$$

$\mathrm{UCR}$ is the uranium corrosion rate in grams uranium per day, $\mathrm{K}^{*}$ is the rate constant for uranium corrosion at a given temperature and environment, in typical units of $\mathrm{gU} / \mathrm{cm}^{2} \mathrm{~d}, \mathrm{~A}_{\mathrm{T}}$ is the true surface area, $R$ is an effective roughness factor for the corroding surface, and $A_{G}$ is the geometric area of the corroding surface.

Table 1. Estimated Corroding Surface Areas for Damaged Elements in K East Basin

\begin{tabular}{||l|c|c|c|c|c|c||}
\hline \multirow{2}{*}{ Failure Type } & \multicolumn{3}{|c|}{ Outers } & \multicolumn{3}{c||}{ Inners } \\
\hline & Number & Area Factor & $\begin{array}{c}\text { Total } \\
\text { Area Units }\end{array}$ & Number & Area Factor & $\begin{array}{c}\text { Total } \\
\text { Area Units }\end{array}$ \\
\hline Incipient & 4925 & $0.01 \mathrm{~A}_{\mathrm{UO}}$ & $50 \mathrm{~A}_{\mathrm{UO}}$ & 4830 & $0.01 \mathrm{~A}_{\mathrm{UI}}$ & $50 \mathrm{~A}_{\mathrm{UI}}$ \\
\hline Rupture & 15,900 & $0.25 \mathrm{~A}_{\mathrm{UO}}$ & $4000 \mathrm{~A}_{\mathrm{UO}}$ & 9325 & $0.25 \mathrm{~A}_{\mathrm{UI}}$ & $2330 \mathrm{~A}_{\mathrm{UI}}$ \\
\hline Loose End Cap & 3180 & $1 \mathrm{~A}_{\mathrm{UO}}$ & $3200 \mathrm{~A}_{\mathrm{UO}}$ & 340 & $1 \mathrm{~A}_{\mathrm{UI}}$ & $340 \mathrm{~A}_{\mathrm{UI}}$ \\
\hline Split Cladding & 1330 & $17 \mathrm{~A}_{\mathrm{UO}}$ & $22,600 \mathrm{~A}_{\mathrm{UO}}$ & 165 & $14 \mathrm{~A}_{\mathrm{UI}}$ & $2280 \mathrm{~A}_{\mathrm{UI}}$ \\
\hline & & Total & $30,000 \mathrm{~A}_{\mathrm{UO}}$ & & Total & $5000 \mathrm{~A}_{\mathrm{UI}}$ \\
\hline
\end{tabular}

${ }^{1}$ This relates to the bounding assumption that the surface-to-volume ratio of failed fuel is 220 $\mathrm{m}^{2} / \mathrm{m}^{3}$, corresponding to a fully-declad element. 
For uranium corrosion occurring on fuel stored in the K East Basin, the value for UCR is estimated from the daily steady state release rate of ${ }^{137} \mathrm{Cs}$, based on the observation that when uranium metal corrodes in water, essentially $100 \%$ of the isotope is released to the water (Tyfield 1988). At the basin water temperature of $10^{\circ} \mathrm{C}$, with water conductivity near $1 \mu \mathrm{S} / \mathrm{cm}$, the steady state rate of ${ }^{137} \mathrm{Cs}$ release is $1.3 \mathrm{Ci} / \mathrm{d}$. Selecting a representative value for the ${ }^{137} \mathrm{Cs}$ concentration in the $\mathrm{N}$ Reactor fuel inventory is complicated by the range of fuel enrichments and decay times. Using an average value of $5.9 \times 10^{-3} \mathrm{Ci}^{137} \mathrm{Cs} / \mathrm{gU}$, the estimated uranium metal corrosion rate in $\mathrm{K}$ East Basin is $200 \mathrm{gU} / \mathrm{d}$ (rounded).

In a prior publication (Johnson and Burke 1995), literature values for $\mathrm{K}^{*}$ were applied for oxygenated and deoxygenated cases. Because the $\mathrm{K}$ Basin water is saturated with oxygen (e.g., $12 \mathrm{ppm}$ at $10^{\circ} \mathrm{C}$ ), the oxygenated case might be expected to apply. However, there is a lack of literature data for uranium corrosion in oxygenated water, so a value for oxygenated water vapor at $10^{\circ} \mathrm{C}$ was applied. This suggested a true surface area that was unrealistically large. When a literature value for uranium corrosion in deoxygenated water was applied, the calculated "true" corroding area was about $15 \%$ of the total declad area of damaged fuel elements in K East Basin. Dividing the geometric area determined from visual inspection into the calculated "true" area based on ${ }^{137} \mathrm{Cs}$ data results in an inferred roughness factor of 18 , which is currently regarded as too high and having a questionable basis, due to the uncertainty that the literature value of the corrosion rate constant is relevant. This will be addressed further in an ongoing assessment by Cooper and Johnson. 
.

.

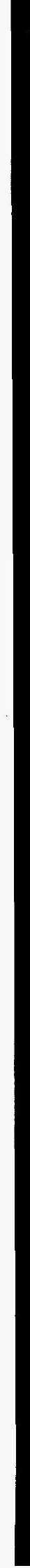




\subsection{CHARACTERIZATION OF FACTORS THAT DEFINE TRUE SURFACE AREA OF CORRODING N REACTOR FUEL}

In Section 4.1.1, the geometric area of the corroding $N$ Reactor fuel was estimated. In Section 3.0 , the factors that define the true surface area were introduced. In the following sections, the significance of the factors is examined.

\subsection{Porosity in Uranium Metal During Irradiation}

British investigations have indicated that corrosion rates on uranium metal fuels with higher burnups (up to $9800 \mathrm{MWd} / \mathrm{MT}$ ) are orders of magnitude higher than corrosion on low burnup fuel (Tyfield 1988). The cause of the accelerated corrosion is porosity that greatly increases the surface area close to the surface of the uranium. The band of porosity is attributed to neutron flux peaking near the metal surface, generating higher concentrations of fission gas that reside in a service temperature range that promotes formation of gas bubbles.

Comparison of the $\mathrm{N}$ Reactor fuel service conditions to those that generated porosity in the British Magnox uranium fuel indicates that the burnup range for the $\mathrm{N}$ Reactor fuel is markedly lower than burnups that resulted in major porosity in the British fuel (Duckworth et al. 1988; Harris 1974). Pitner ${ }^{2}$ related the fuel burnup to failure type in the KE Basin fuel inventory. The data show that greater than $99 \%$ of the failed fuel elements have burnups of $3000 \mathrm{MWd} / \mathrm{MT}$ or below. Examination of an N Reactor fuel element from a K West (KW) Basin canister has not shown evidence of porosity (Abrafah 1996). A study by Goffard and Last (1964) indicated that swelling of irradiated N Reactor fuel was only $3.6 \%$ at $3100 \mathrm{MWd}$ MT. However, a small fraction of the N Reactor fuel has burnups (up to $7100 \mathrm{MWd} / \mathrm{MT}$, without applying local power factors ${ }^{3}$ that fall near the onset of increased porosity. At the highest burnup, the extrapolated swelling is $\sim 10 \%$, based on extension of the Goffard and Last (1964) data. However, this degree of swelling applies to a small fraction of the N Reactor fuel.

If porosity has developed in the high-burnup $\mathrm{N}$ Reactor fuel, the location is likely to be similar to the British fuel, i.e., small pores near the metal surfaces. On the large fraction of the corroding $\mathrm{N}$ Reactor fuel cross section, porosity is likely to be negligible. If significant porosity has developed on the higher burnup $\mathrm{N}$ Reactor fuel, it seems likely that accelerated local attack would result in a ring of pits near the edges of the metal cross sections, but that the large majority of the metal cross section would be subject to normal corrosion. Thus, if corrosion

\footnotetext{
${ }^{2}$ Personal Communication, A.L. Pitner, Westinghouse Hanford Company, to A.B. Johnson, Pacific Northwest National Laboratory, January 1996.

${ }^{3}$ Memorandum from S.P. Roblyer, Westinghouse Hanford Company, to J.J. Irwin, Westinghouse Hanford Company, "K Basin Fuel Decay Heating Characterization," January 12, 1996.
} 
of the N Reactor fuel occurs on cross section surfaces, porosity will not be a substantial source of highly accelerated corrosion. It is not clear how porosity will enter into accelerated corrosion of fuel with split cladding without a clearer indication of the configuration of the corroding surface.

\subsection{Surface Area That May Arise from Microcracking of Uranium Metal Fuel}

Irradiation embrittles uranium metal (Swanson et al. 1985, p. 7.11). Therefore, the shock that resulted in cladding damage during fuel discharge from the reactor also could generate microcracks in the metal. Whether microcracks are a real phenomenon would have to be determined in examinations of corroding elements. To date, examination of a failed element, stored in a KW Basin canister, has not revealed discernible microcracking at locations approximately 12 in. $(30 \mathrm{~cm})$ from the corroding surface (Abrefah 1995). The condition of the uranium close to the corroding surface is under investigation.

If microcracks do exist in the uranium metal near damage sites, the next consideration is how they enter into initiation and propagation of corrosion and possible ignition. Transport of oxidant into the microcracks would seem to be diffusion-limited while the cracked metal remains compact (Swanson et al. 1985, p. 7.11). Therefore, the effective surface area may be approximated by the corroding area, to the extent that the metal remains compact, e.g., unless oxide wedging or other factors expose surfaces of the microcracks.

Insights to microcracking from the current and future $\mathrm{N}$ Reactor fuel examinations will be important to evaluate the potential impact of microcracking on true surface area of corroding elements.

Swanson (1988) alluded to an irradiated failed N Reactor fuel element that had corroded for 12 years in water. The element reacted extensively in nitric acid because the metal fuel "fell apart" after decladding, suggesting that the metal was segmented, apparently during attack by decladding solution. One hypothesis involved hydriding along grain boundaries, that provided locations for accelerated attack by the aggressive solution. Otherwise, Swanson reported that dissolution rates of uranium metal fuel in nitric acid had no dramatic dependance on irradiation exposure.

\subsection{Roughness Factors for Corroding Uranium Metal Fuel}

Every metal surface has asperities that result in a true surface area that is larger than the geometric area. The relationship is

$$
A_{T}=R_{G}
$$

where $A_{G}$ is the geometric area, $A_{T}$ is the true surface area, and $R$ is a roughness factor that is defined by the number and size of asperities. 


\subsubsection{Methods to Determine Roughness Factors on Metals}

Several methods have been used to estimate true surface areas of metals (Johnson 1962). Gas absorption on metal surfaces by the Brunnaer, Emmett, and Teller (BET) method has been applied to relatively small, nonradioactive specimens. The method involves measurement of adsorption isotopes for gases at slightly above their boiling points (e.g., the boiling point of nitrogen is $-196^{\circ} \mathrm{C}$ ). Polarization capacitance has been used to estimate roughness factors on metal surfaces. The concept involves measurement of the capacitance of a metal surface placed in an electrolytic solution. Because the electrical double layer follows the metal surface contours on a microscale, the capacitance is proportional to the area of surface asperities. Roughness factors for several metals and surface conditions are provided in Appendix C.

\subsubsection{Macro Roughness Factors on Corroding Uranium Metal}

Figure 5 shows areas on corroding unirradiated uranium metal (Howell 1995). Asperites are evident. Surface roughness estimated for Figure $1 \mathrm{~b}$ resulted in a macro roughness factor of 1.3. The factor for the surface in Figure 1c is 2.4. However, the magnifications are too small to accommodate estimates of $R$ that include contributions from micro roughness. A macro roughness estimate was made on a corroded irradiated uranium surface exposed to a $\mathrm{NaOH} /$ $\mathrm{NaF}$ solution at $30^{\circ} \mathrm{C}$ (Tyfield 1988). The estimated macro roughness factor is 1.5 .

\subsubsection{Calculated Roughness Factors}

Prior calculation, assuming an ideal surface, indicated an $\mathrm{R}$ value of 2 for a surface comprising pyramidal asperities one micron wide and one micron slant height (Johnson 1962). When smaller asperities were superimposed on the larger asperities ( $50 \AA$ base and slant height), the calculated roughness factor was 4 . In lieu of a satisfactory basis for determining $R$ for the corroding $\mathrm{N}$ Reactor fuel, a value of 4-5 may be realistic for corroding uranium metal.

\subsubsection{Roughness Factors that Develop on Irradiated N Reactor Fuel in Nitric Acid}

Swanson et al. (1985) estimated surface roughness increases during initial reaction of uranium metal fuel with nitric acid. The surface roughness increase in $3 \mathrm{M}$ nitric acid was 2.4 , compared to the rate on as cut specimens. In $5 \mathrm{M}$ nitric acid, the surface area increase was 4 . These values may relate nominally to surface roughness increases as uranium metal corrodes in water.

\subsection{Other Phenomena that Could Contribute to True Surface Area of Corroding N Reactor Fuel}

Internal active surface areas sometimes occur for metals susceptible to intergranular phenomena. Corrosion on unirradiated uranium metal was reported (Figure 5), but magnifications were too low to determine whether an intergranular mechanism was involved (Howell 1995). 


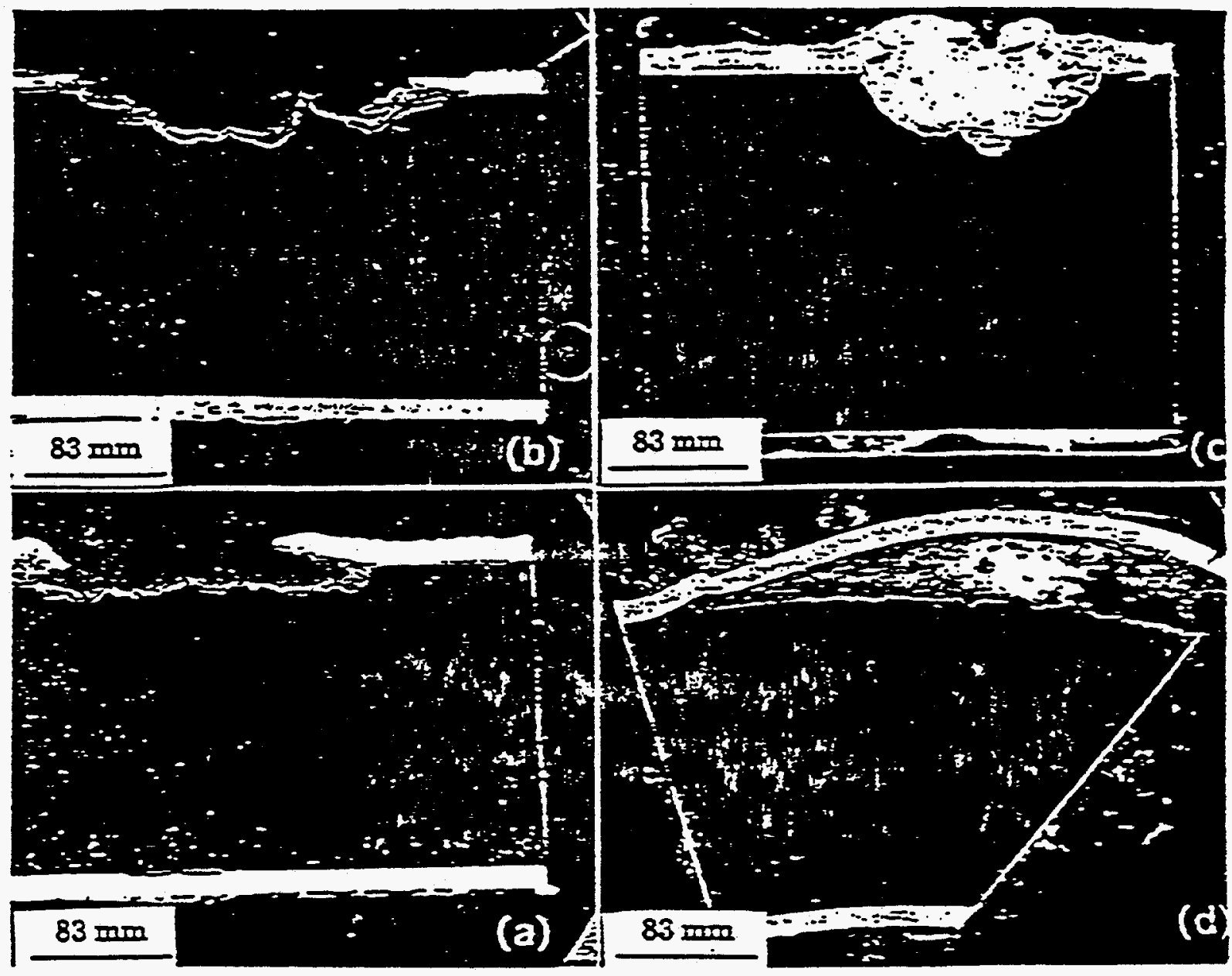

Figure 5. Four typical pit types found on unirradiated target, after corrosion in a fuel storage pool over five years: (a) shallow corrosion penetration of uranium core, (b) deeper penetration of uranium core, (c) vertical penetration of uranium core, (d) bubble formed under aluminum cladding; magnification $=5 x$ (Howell 1993). 
However, recent inspection of the corroding surfaces at higher magnifications clearly confirms that an intergranular corrosion mechanism was involved ${ }^{4}$ (see Figure 6). The corrosion occurred in rather impure water (up to $150 \mu \mathrm{S} / \mathrm{cm}$ ), so it is not clear that the intergranular mechanism will apply in the $\mathrm{KE}$ Basin and $\mathrm{KW}$ Basin waters.

Tyfield (1988) indicates that aqueous corrosion of irradiated reactor-grade uranium is generally similar to corrosion of unirradiated material, unless radiation-enhanced porosity has developed, as indicated earlier.

As indicated above for tight microcracks, transport of active species along corroding grain boundaries also may be diffusion-limited, mitigating effects on propagation of corrosion from internal surface area effects.

${ }^{4}$ Personal Communication from J.P. Howell, Westinghouse Savannah River Company, to A.B. Johnson, Pacific Northwest National Laboratory, April 8, 1996. 
- (E66I IIəMOH) S.eəК

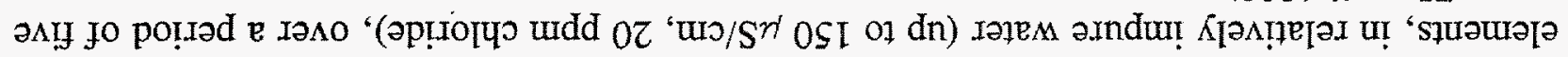

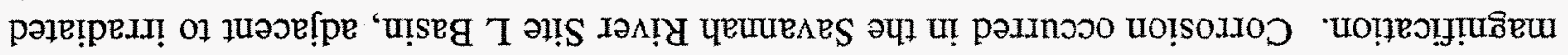

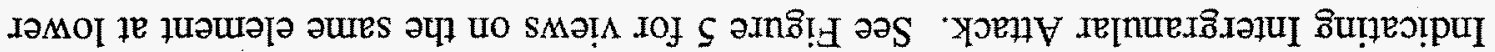

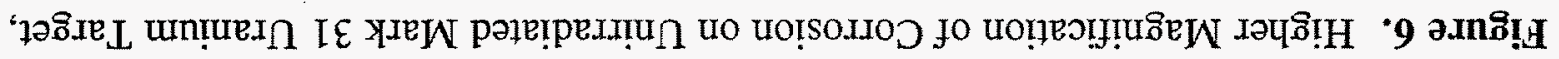

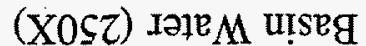

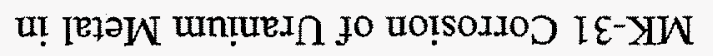

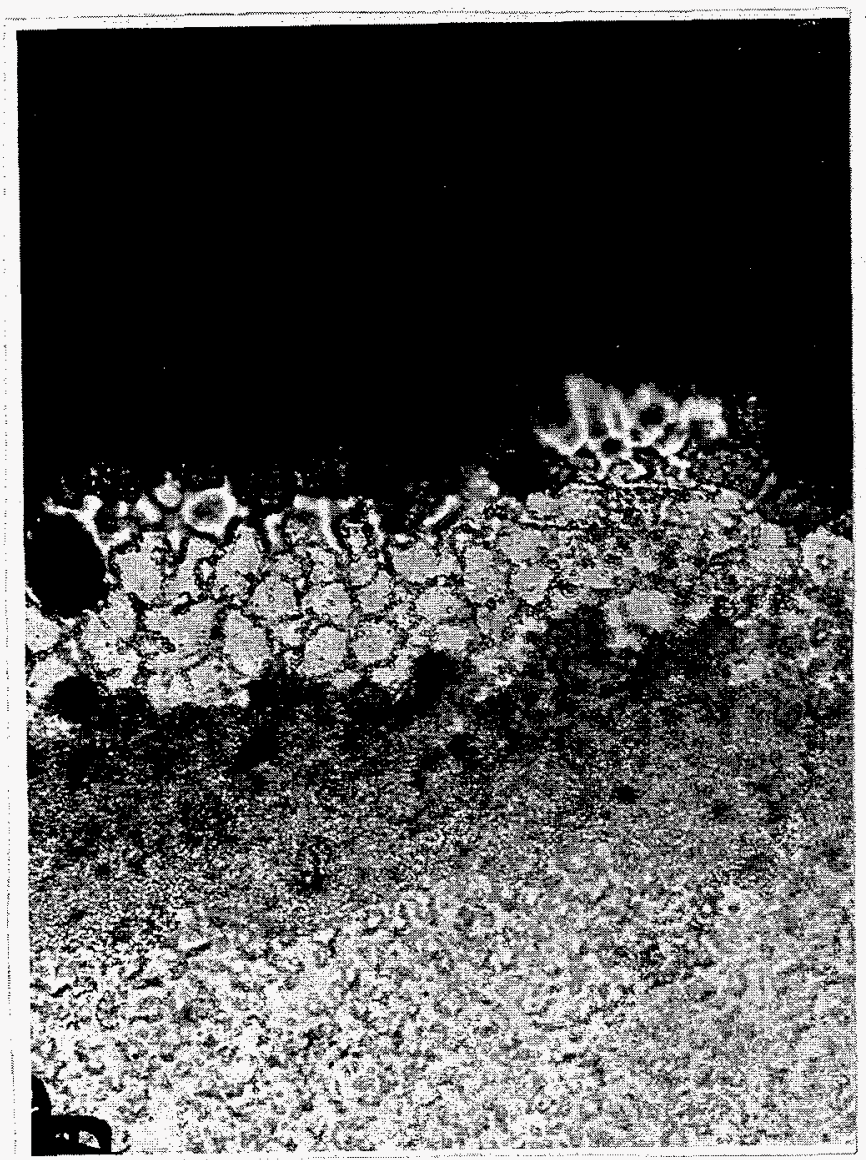

(X00I) دәाе $M$ uiseg

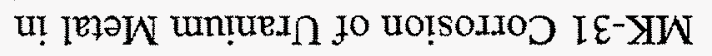

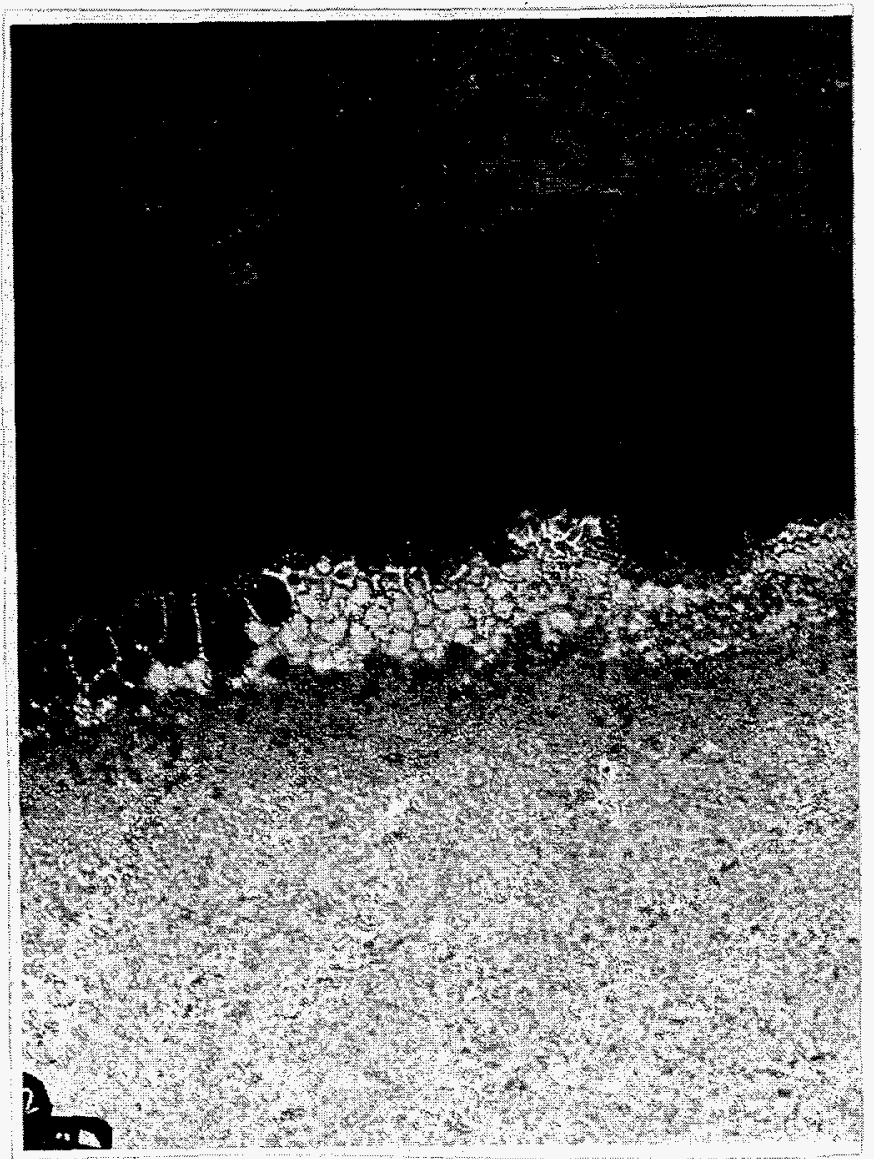




\subsection{CONTRIBUTIONS OF FUEL RUBBLE TO CORRODING URANIUM SURFACE AREA IN MCOS}

The concept to place fuel rubble into the MCOs imposes an additional, important consideration on the estimation of exposed uranium surface area in the MCOs. The estimate may be approached from two directions. The first is an analytical approach, based on assuming a distribution of uranium metal particle sizes and calculating the resulting surface area. The other approach is to revisit the visual observations of fuel stored in the KE Basin to derive an empirical estimate of the area of fuel segments that may be placed in the rubble containers. Neither approach can accurately anticipate the characteristics or inventory of metal segments that will be generated in fuel handling. However, it seems useful to describe the characteristics of the KE Basin fuel that may contribute to the rubble inventory, based on the visual inspections. It also seems relevant to revisit observations from the 1983/84 Segregation Campaign regarding generation of metal segments during fuel handling.

This assessment involves an estimate of the fuel segments that were apparent when the fuel in $\mathrm{KE}$ was visually inspected, an estimate of the associated surface area and observations of staff that participated in the Segregation Campaign regarding the metal segment inventory. It is first important to explore a working definition of rubble.

\subsection{Definition of Rubble}

As indicated earlier, there is first a need to agree on terminology regarding uranium fuel segments. There seems to be general agreement that the term debris refers to nonfuel pieces, such as fuel spacers, that were retrieved and placed in canisters after the Segregation Campaign. The terms chip canisters and scrap canisters have been used to denote storage of fuel segments that resulted from the Segregation Campaign. The term rubble has sometimes been used to denote nonfuel debris. Therefore, it is proposed that when fuel segments are denoted, that the term fuel rubble be used.

One definition (L/B-SD-SNF-RPT-09 1996) suggests that all fuel material greater than 3 in. $(7.5 \mathrm{~cm})$ in any dimension is considered fuel. Fuel material less than 3 in. in any dimension is considered "bits" (fuel rubble).

A second working definition is based on the concept of maximizing the packing of fuel in fuel baskets. In this case, lengths of fuel elements, e.g., up to 12 in. $(30.5 \mathrm{~cm})(1 / 2$ of the maximum element length) would represent the maximum fuel rubble size. The minimum size involves fuel particles that are retained on a $1 / 4$-in. $(0.63-\mathrm{cm})$ screen. If all particle diameters were 0.25 in., the ratio of geometric area to volume (A/V) would be 950 , not accounting for effects of surface roughness. 
A third, engineering perspective on fuel rubble, involves the observation that nondeformed lengths of elements (less than full length but $>3$ in. segments) were stacked in a singleelement location in the Segregation Campaign. On the other hand, if a full-length element is deformed, it will be difficult to place in a fuel canister and could be most readily disposed of in the rubble container. It seems necessary to focus the above rubble concepts into a single working definition that is widely embraced as addressing both technical and engineering concerns.

There is general agreement that uranium particles with sizes $>1 / 4 \mathrm{in}$. will be classified as rubble. Some fuel segments up to $11 \mathrm{in}$. have been placed in uranium scrap cans, and there is a recommendation that it may be more practical to regard full sized, distorted elements as rubble, rather than dealing with difficulties in placing them in normal fuel positions. It is not an intent of this treatment to resolve the definition of the upper bound for fuel segments regarded as rubble, but to infer from the diversity of perspectives that a practical basis for a definition needs to be agreed to.

\subsection{Observations from the Segregation Campaign Relevant to Rubble}

In the 1983/84 Segregation Campaign, approximately 5000 fuel canisters stored in the $\mathrm{KE}$ Basin were emptied onto a metal table and the fuel was sorted. Some was sent for reprocessing and the rest remained in the basin. About half of the fuel assemblies were disassembled, i.e., the outer and inner elements were separated. To summarize observations: ${ }^{5}$

- some fuel fragments were observed from elements broken in discharge; where element fragments could be matched up, they were placed together into storage canisters; a few $2-3$ in. $(5-7.5 \mathrm{~cm})$ segments were placed in scrap canisters; not many metal segments $<3$ in. were observed

- some end caps separated from the elements; there did not appear to be significant metal attached to the end caps

- if the broken fuel segment was 6 in. $(15 \mathrm{~cm})$ or more, it was placed on an inner; the inners almost never had sections missing

- not many metal fragments were observed when split cladding elements were emptied onto the sorting table; in general what came out was like black sand that settled quickly, appearing to leave almost empty cladding

\footnotetext{
${ }^{5}$ Based on discussions with V.L. Hoeffer and J.D. Mathews, Westinghouse Hanford Company, Richland, Washington, April 18, 1996.
} 
- Zircaloy "buggy spring" spacers generally separated during element disassembly, but most carbon steel feet remained on the elements. These were placed in debris canisters; while there may have been an intent to fully exclude fuel segments from the debris canisters, unless there is process evidence of complete segregation, the assurance that fuel segments are absent may need verification.

The fuel rubble from the handling operations was placed into $\sim 10$ canisters. Records regarding the contents of these canisters or their exact number have not been retrieved. It seems important to access the records before an estimate of the fuel rubble area is attempted. The oxides on the corroding segments in the fuel rubble canisters will have a moisture inventory that will be transported into the MCOs unless the oxides are removed.

Since 1992, 26 canisters $^{6}$ (52 barrels) were filled with debris when the discharge chute was cleaned up.

\subsection{Contributions to Rubble Based on Video Inspection of KE Basin Fuel}

Inspections by Pitner (1995) provide a basis to assess the fuel-related segments that are visible. On one hand, results of the inspections provide a reality check on the obvious fuel segments that may be classified as rubble. On the other hand, the observations do not include, for example, visibility inside the "split cladding" elements (Figure 4) to characterize the degree of fuel segmentation. As fuel is emptied onto the process table, it seems likely that "incipient" (Figure 1) and "rupture" (Figure 2) element categories will contribute relatively little to rubble. The elements corroding on full cross sections (Figure 3) generally seem compact, but it is not clear whether fuel fractures occurred during discharge that will allow fuel segments to be expelled during jarring associated with emptying and sorting operations. With more advanced corrosion, fuel segmentation could be more pronounced in the upcoming campaign. Potentially the most likely to involve fuel segments is the "split cladding" category (Figure 4).

Disassembly of fuel elements was a major operation in the Segregation Campaign that will not be repeated in the upcoming campaign to transition the $\mathrm{N}$ Reactor fuel to dry storage. This may mitigate fuel segmentation during fuel handling operations.

\subsection{Perspectives on Types of Fuel Segments from Visual Inspection of Fuel in the KE Basin}

A recent review of the 1994 video survey of fuel in the KE Basin indicated the following forms that could be interpreted as rubble (Figures 7 and 8 ):

- broken fuel elements

${ }^{6}$ Referred to as scrap cans. 


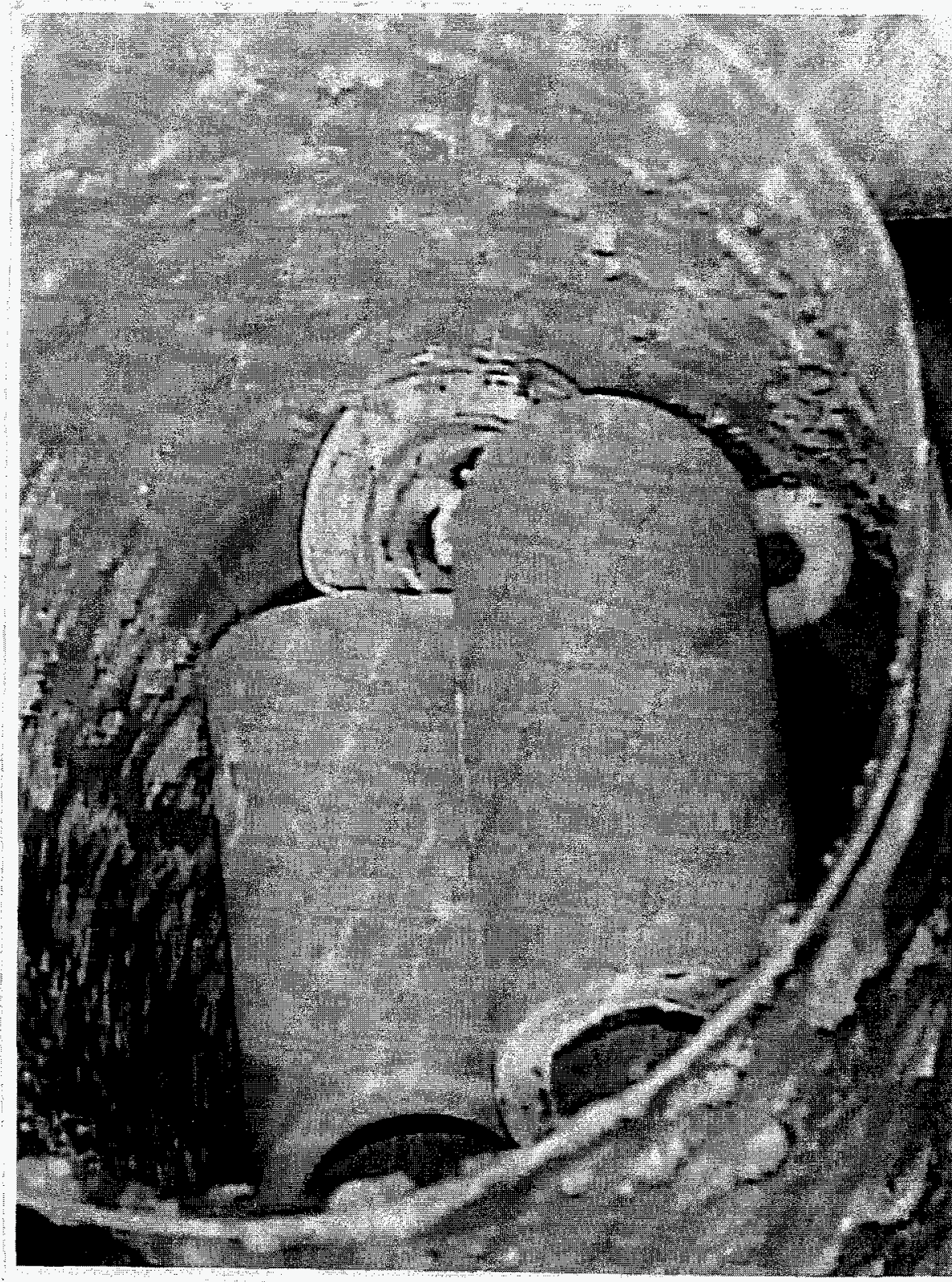

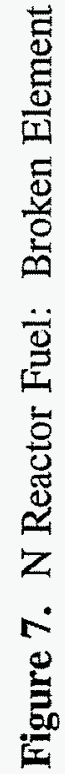




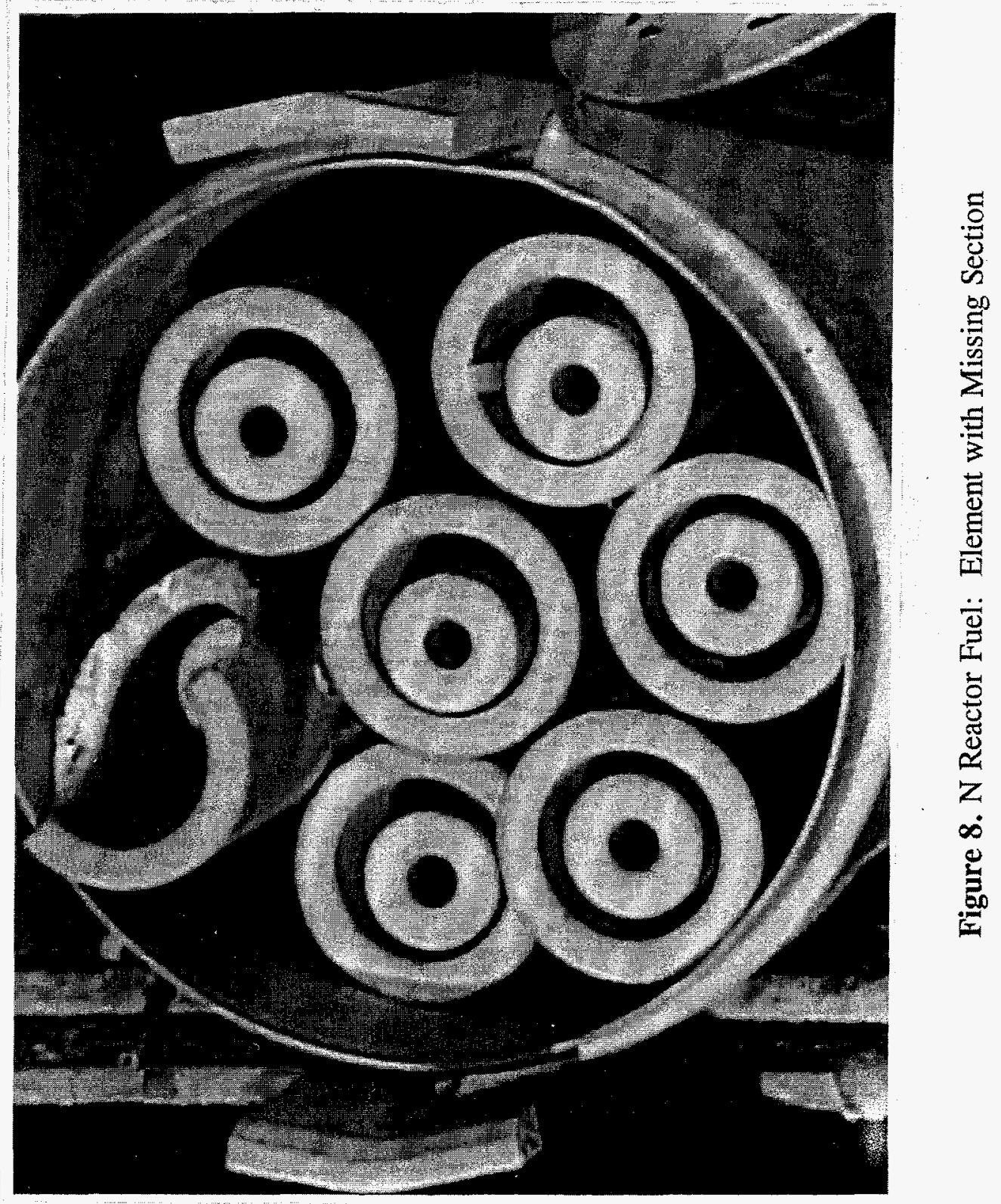


- loose end caps

- reacted fuel particles.

Numerous cases of broken ends of outer fuel elements were evident. The general geometry of the fractures are consistent with exposing one outer area unit to corrosion (one from each end of the broken pair) for each broken segment placed in a rubble canister. About 20 of these cases were observed in the survey. Assuming that equal frequencies occur on the bottom ends of the elements and adjusting for $30 \%$ of the canisters that were not visible, yields the following outer area units:

$$
20 \times 2 / 0.7=57 \mathrm{~A}_{\mathrm{UO}}
$$

There are also about 20 locations where deflections in the fuel element profile suggest breakage near the longitudinal center of the element. Each breakage would add one area unit to the rubble container if one of the segments is $<3$ in. $(7.6 \mathrm{~cm})$. The corroding area would add another $\sim 30 \mathrm{~A}_{\mathrm{UO}} \mathrm{s}$ to the rubble canister.

The second source of rubble is detached end caps. It is seldom evident whether fuel is attached to the end cap. However, in conducting a recent ultrasound inspection, a detached end cap was flipped over by the measuring probe. Definite indications of fuel remnants were observed on the fuel side of the end cap. A conservative estimate of the potential metallic fuel surface area from this source would be equal to the Loose End Cap Area given in Table 1, i.e., $3200 \mathrm{~A}_{\mathrm{UO}}$ and $340 \mathrm{~A}_{\mathrm{UI}}$.

Reacted fuel particulate is fuel that has corroded and escaped from the element through split cladding. Previous estimates of the volume of this oxide material suggested inventories as high as $200,000 \mathrm{~cm}^{3}$. However, the visual interpretation suggests that it is reacted uranium oxide (consistent with observations during the Segregation Campaign). Therefore, it does not contribute to the corroding metal surface area.

The total metallic area constituting observable fuel rubble is

$$
\begin{array}{ll}
\text { Broken outer elements } & 85 \times 14=1,200 \mathrm{~cm}_{2} \\
\text { Loose outer end caps } & 3200 \times 14=44,800 \mathrm{~cm}^{2} \\
\text { Loose inner end caps } & 340 \times 7.2=2,500 \mathrm{~cm}_{2} .
\end{array}
$$

The total geometric area of potentially corroding uranium is about $5 \times 10^{4} \mathrm{~cm}^{2}$.

It is expected that additional fuel particles will be expelled during fuel handling. However, no large inventories of small metal particulates were observed in the Segregation Campaign. Large numbers of Zircaloy "buggy spring" fuel spacers were observed in the Segregation 
Campaign. However, these will not be a significant factor in the upcoming campaign because it is not planned that fuel elements will be disassembled.

The visual inventory of potential $\mathrm{KE}$ Basin rubble components is provided above, and the associated area of corroding uranium is estimated. However, the dominant contribution comes from outer end caps, where some evidence of residual uranium metal was observed, but on many end caps the uranium metal may have fully corroded.

\subsection{Fuel Rubble Considerations in the $\mathrm{K}$ West Inventory}

There are 12 fuel chip canisters stored in $\mathrm{K}$ West. They came from fuel operations at $\mathrm{N}$ Reactor Basin. The fuel segment sizes are not indicated on the records. Each canister contains less than $180 \mathrm{lb}(82 \mathrm{~kg})$ of fuel on a dry weight basis. The fuel is regarded as Mk IA, $1.25 \%$.

The inventory of fuel in the closed KW Basin canisters has not been available for inspection to identify rubble components. In general, the components may be similar to those identified for the $\mathrm{KE}$ Basin. However, the KW Basin inventory was not subject to sorting paralleling the Segregation Campaign. Therefore, fuel segments already removed to scrap canisters in the $\mathrm{KE}$ Basin may have parallel segments in KW Basin canisters. Because the KW Basin fuel assemblies are not intended to be dissembled, fuel spacers that were a major element of debris in the KE Basin will not be a factor in the KW Basin. 



\subsection{CONCLUSIONS}

The following surface area factors are suggested for the corroding uranium in the $\mathrm{N}$ Reactor fuel:

- Fraction of the uranium metal area on damaged elements (estimated to be $\sim 42 \%$ of outer elements and $\sim 27 \%$ of inner elements) that is corroding: $\sim 1 \%$ :

- The estimated geometric area of the corroding surfaces on $\mathrm{K}$ East fuel elements is $\sim 5 \times 10^{5} \mathrm{~cm}^{2}$, based on observations by Pitner, using underwater video. The total area of uranium metal in damaged fuel elements, if declad, would be $60 \times 10^{6} \mathrm{~cm}^{2}$. Therefore, the estimated geometric area represents $0.8 \%$ of the total area of the damaged elements in the $\mathrm{K}$ East inventory

- Porosity:

- $>99 \%$ of the damaged N Reactor fuel in K East has burnups of 3,000 MWd/MT or less, with corresponding swelling of $3 \%$ or below; this degree of porosity is not likely to substantially influence corrosion, based on British data

- $10 \%$ porosity for a few high burnup elements (up to 7,100 MWd/MT); likely to lead to pitting attack in a narrow band near edges of the element if corrosion is occurring on cross sections

- With the exception of possibly on a few elements, porosity is expected to have a small or negligible effect on $\mathrm{N}$ Reactor fuel corrosion.

- Microcracks:

- Area effects from microcracks in uranium metal: no cracks observed on the $\mathrm{KW}$ Basin fuel element 12 in. $(30.5 \mathrm{~cm})$ from reacting surface; results near reaction zone pending. Assume that transport in tight cracks, if present, will be diffusionlimited. Swanson (1988) observed segmentation of N Reactor fuel, but hypothesized that segments were generated by attack on hydrided uranium grain boundaries by decladding solution.

- Roughness factors for corroding uranium metal:

- Estimates for macro roughness on corroded uranium surfaces indicate $R$ values of 1.3, 1.5 , and 2.4 respectively; based on roughness factors for other metals and calculated roughness factors, assume a value of 4-5 for the $\mathrm{N}$ Reactor fuel; Swanson observed surface roughening by factors of 2.4 to 4 on uranium metal from attack by nitric acid. 
Roughness factors of 4 to 5 seem more credible than the value of 18 from ratioing the estimated geometric and "true" surface areas from video inspections of $\mathrm{KE}$ fuel and ${ }^{137} \mathrm{Cs}$ data from corrosion of $\mathrm{KE}$ fuel

- Other area-enhancing phenomena:

- Intergranular phenomena were observed on corroding uranium (Howell 1995), but whether they apply to corroding $\mathrm{N}$ Reactor fuel will remain unknown until hot cell examinations are completed.

- Rubble:

- The plan to place rubble canisters into the MCOs will add to the surface area of corroding uranium; there are known fuel rubble inventories in both $\mathrm{K}$ East and $\mathrm{K}$ West. There are 12 fuel chip canisters in the $\mathrm{K}$ West inventory. There is an estimate that about 10 canisters were filled with fuel rubble in the Segregation Campaign, but the exact number and information regarding the fuel segment sizes has not been determined. There are two canisters that contain fuel segments from the 1992/93 cleanup campaign, but one has already been counted as a fuel canister in Pitner's visual inspection campaign. Zircaloy and carbon steel parts were placed in debris canisters after the Segregation Campaign. Discussions with staff involved in the campaign suggest that complete segregation fueled and nonfueled debris should not be assumed unless the records support that position.

- Types of rubble were assessed from the 1994 video campaign; types included broken outer elements and loose end caps. The estimated corroding area is $5 \times 10^{4} \mathrm{~cm}^{2}$. This does not include metal segments and particles released in fuel handling operations. Discussion of the Segregation Campaign suggests that metal segments and particles were not prominent as the fuel was handled. 


\subsection{REFERENCES}

Abrafah, J., G.L. Ketner, T.D. Pyecha, W.J. Gray, S.C. Marschman, and T.A. Thorton. 1995. K-Basin Spent Nuclear Fuel Characterization Data Report. PNL-10778, Pacific Northwest National Laboratory, Richland, Washington.

Ballinger, R.G., A.B. Johnson, Jr., and K.A. Simpson. 1994. "Kinetic and Thermodynamic Bases to Resolve Issues Regarding Conditioning of Uranium Metal Fuels," PNL-SA-24458, Pacific Northwest National Laboratory, Richland, Washington. In Proceedings of ANS Meeting, US Department of Energy Spent Nuclear Fuel - Challenges and Initiatives, December 13-16, 1994 (poster paper, not included in the bound proceedings).

Duckworth, F.C., R.A. Holm, T. Molloy, and D Rhodes. 1988. "Performance of Magnox Fuel Elements at Peak Element Irradiation up to 9,000 Mwd/t." Nuclear Energy 27(1):99-107.

Goffard, J., and W.G.A. Last. 1964. Swelling Behavior of N Reactor Fuel Elements. HW 79646, General Electric Company, Richland, Washington.

Harris, J.E. 1974. "Getting the Most from Magnox Fuel." CEGB Research 1:29-85 (Berkeley, United Kingdom), Central Electric Generating Board.

Howell, J.P. 1993. "Metallography of Pitted Aluminum-Clad, Depleted Uranium Fuel." In Corrosion 95, Paper No. 430, National Association of Corrosion Engineers, International, Houston, Texas.

Johnson, A.B. 1962. Surface Properties of Metals by Polarization Capacitance Measurements. ARL 62-376, Aeronautical Research Laboratories, Wright Patterson Air Force Base, Ohio.

Johnson, A.B., Jr. and S.P. Burke. 1995. K Basin Corrosion Program Report. WHC-EP0887, Westinghouse Hanford Company, Richland, Washington.

Pitner, A.L. 1995. K East Basin Visual Survey. WHC-SD-SNF-TI-012, Westinghouse Hanford Company, Richland, Washington.

Swanson, J.L., L.A. Bray, H.E. Jarmo, J.L. Ryan, C.L. Masuzaki, S.G. Pitman, and J.H. Haberman. 1985. Laboratory Studies of Shear/Leach Processing of Zircaloy Clad Metallic Uranium Reactor Fuel. PNL-5708, Pacific Northwest Laboratory, Richland, Washington.

Swanson, J.L. 1988. Recent Studies Related to Head-End Fuel Reprocessing at the Hanford PUREX Plant. PNL-6609, Pacific Northwest Laboratory, Richland, Washington. 
Tyfield, S.P. 1988. "Corrosion of Reactor Grade Uranium in Aqueous Solutions Relevant to Storage and Transport." Nuclear Energy 27(2):91-98. 
APPENDIX A

ESTIMATE OF CORROSION ON N FUEL IN THE KE BASIN 



\section{APPENDIX A \\ ESTIMATE OF CORROSION ON N FUEL IN THE KE BASIN}

The corroding upper ends of elements in canisters in the KE Basin are visible. Predominantly, what is seen is uranium oxide corrosion products covering the corroding surface. However, in some cases, voiding of the corrosion products has occurred. Pitner estimated the depth of corrosion and voiding (Johnson and Burke 1995, Attachment 2). Estimates by two observers differed by a factor of two; the ranges were 0.5 to 5 in. One observer estimated that $75 \%$ of the elements where corrosion was evident had lost 1 in. or less of the fuel. The other observer estimated that $35 \%$ of the fuel had lost 1 in. or less. The average of the two observers is that $55 \%$ of the fuel lost $1 \mathrm{in}$. or less of the fuel length. Using a nominal metal fuel length of 25 in., loss of 1 in. of fuel length represents $4 \%$ of the metal. Maximum estimated fuel loss was 3 in. for one observer and 5 in. for the other observer. However, the extremes represented less than $1 \%$ of the fuel. A rough estimate of the weighted average of the two observers suggests that less than 2 in. (8\%) of the fuel had corroded. On fuel where the corrosion product remains in place, the depth of corroded uranium is not evident, but is not likely to be more than on the elements where voiding of the corrosion products was evident. This suggests that a value of $10 \%$ would bound the extent of fuel that has corroded on elements where corrosion is evident.

Another method was used to estimate the total uranium metal corrosion that has occurred while the $\mathrm{N}$ Reactor fuel has been stored in the KE Basin. The method involves an estimate of the integrated ${ }^{137} \mathrm{Cs}$ released to the basin water. The rough estimate suggests that about $1 \%$ of the uranium metal in the damaged elements has corroded (Johnson and Burke 1995).

Based on the two estimates, the amount of uranium metal stored in KE Basin that has corroded lies between 1 and $10 \%$, so an upper bound of $10 \%$ seems conservative. However, this value is provided as a general perspective that does not directly define the corroding surface area. 



\begin{abstract}
APPENDIX B
SUMMARY OF DATA NEEDS TO RESOLVE UNCERTAINTIES REGARDING SURFACE AREA FACTORS FOR N REACTOR FUEL
\end{abstract}





\section{APPENDIX B}

\section{SUMMARY OF DATA NEEDS TO RESOLVE UNCERTAINTIES REGARDING SURFACE AREA FACTORS FOR N REACTOR FUEL}

This list is developed with the understanding that it is not realistic to address all factors in depth. Where initiatives are practical, the information would improve the perspective of corroding surface area, which is one of the important parameters in predicting fuel behavior, for example, in ignition events.

The list of data needs and uncertainties is as follows:

1. What is the incidence of the four fuel failure categories on the lower ends of the KE Basin fuel elements?

2. What is the incidence of the four fuel failure categories in the $30 \%$ of $\mathrm{KE}$ Basin fuel canisters not available for observation?

3. What is the corrosion rate of $\mathrm{N}$ Reactor uranium metal in KE Basin water conditions?

4. Is radiation-induced porosity evident or expected in any corroding $\mathrm{N}$ Reactor fuel elements? If observable, what is the morphology of the attack (for a corroding cross section, a row of pits immediately under the metal surfaces would be expected for highly porous fuel)?

5. Is microcracking evident at corroding locations on the $\mathbf{N}$ Reactor fuel? If so, what is the character of the cracks: tight, uncorroded, separated and corroding, or other phenomena?

6. What are the macro roughness factors for corroding areas on the N Reactor Fuel (compare Figures 5 and 6$)$ ?

7. Is intergranular attack evident on corroding areas of KE Basin and KW Basin fuel (see Figure 7 for uranium metal corroding in a fuel storage basin at the Savannah River Plant)?

8. What is the nature of corroding fuel surfaces inside selected elements in the "split cladding" category? Are there loose corroding metal particles? Do the corroding surfaces have high surface areas? Are there occluded hydride inventories? What is the nature and inventory of corrosion products remaining after mobile products are expelled?

9. What is the expected inventory and size distribution of uranium metal particles generated during fuel handling? 

APPENDIX C

SURFACE ROUGHNESS FACTORS FOR SELECTED METALS AND SURFACE CONDITIONS 


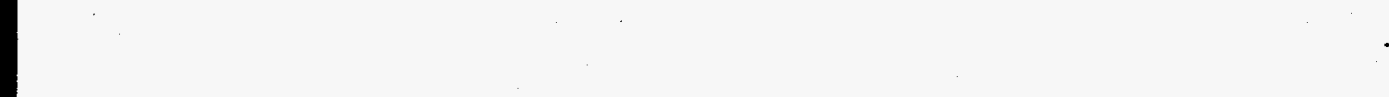




\section{APPENDIX C \\ SURFACE ROUGHNESS FACTORS FOR SELECTED METALS AND SURFACE CONDITIONS}

\section{Methods to Measure Surface Roughness Factor and True Surface Areas for Metals}

The Brunnaer, Emmett, and Teller (BET) method involves adsorption of a monolayer of a gas (argon or nitrogen) onto a metal surface. The monolayer follows the surface contours and therefore provides a measure of the true surface area, based on measurement of the number of gas molecules adsorbed and the known area of a molecule ( $16 \mathrm{~A}^{2} /$ molecule for nitrogen) (see O'Conner and Uhlig 1957).

The polarization capacitance method involves establishing an electrical double layer on a metal surface of a specimen submerged in an electrolyte. Because the double layer follows the metal surface asperities on a microscale, the capacitance of the surface is a measure of the surface area. A roughness factor is determined by comparing the capacitance to the capacitance of an ideally smooth surface, such as liquid mercury or a highly smooth surface of the same metal (see Johnson 1962).

A radiocounting method (Erbacher 1933) was used to compare surface roughnesses for selected metals.

\section{Surface Roughness Values For Selected Metals and Surface Conditions ${ }^{1}$}

From the BET method, the following roughness factors were measured $\left(\mathrm{O}^{\prime}\right.$ Conner and Uhlig 1957):

- hydrogen-reduced iron sheet 1.2

- pickled SS $\quad 4.2$

- abraded SS $\quad 3.1,3.4$

- electropolished SS $\quad 1.1$

${ }^{1}$ Much larger surface roughness factors have been indicated (Johnson 1962). Values in Appendix $\mathrm{C}$ represent a reasonably consistent set of values that illustrate effects of surface treatment. 
Using radio counting, Erbacher measured the following roughness factors:

- polished nickel

- abraded $\mathrm{Ni}, \mathrm{Au}, \mathrm{Ag}$
1.7

2.5

From polarization capacitance, Testerman (1960) reported the following roughness factors:

- abraded copper

- abraded aluminum

- abraded SS

- abraded titanium
3.6, 4.3 (depending on grit size)

$2.2,3.0$

$2.0,2.8$

2.8

Also from polarization capacitance, Johnson (1962) measured roughness factors:

- abraded gold

- abraded platinum
2.2-2.3 and 2.8-3.1, depending on grit size

2.7

\section{Appendix C References}

Erbacher, O.. 1933. Zhurnal Fizicheskoi Khimii 163:215.

Johnson, A.B. 1962. Surface Properties of Metals by Polarization Capacitance. Aeronautical Research Laboratories, Wright-Patterson Air Force Base, Dayton, Ohio.

O'Conner, T.L., and H.H. Uhlig. 1957. J. Phys. Chem. 61:402.

Testerman, M.K. 1960. WADD Technical Report 60-97. Wright Air Development Division, Wright-Patterson Air Force Base, Dayton, Ohio. 


\section{Distribution}

No. of

Copies

OFESITE

$4 \quad$ U.S. Department of Energy 12800 Middleburgh Road

Germantown, MD 20874

E. C. DeLeon, EM-37 (3)

J. Baker

2 Westinghouse Savannah River Company Savannah River Site

Aiken, SC 29808

J. P. Howell

Lockheed Idaho Martin Tech

P.O. Box 1625

Idaho Falls, ID 83415-5217

W. Dirk

\section{ONSITE}

$3 \quad$ U.S. Department of Energy Richland Operations Office

J.-S. Shuen

$57-41$

D. C. Langstaff

DOE Public Reading Room

K8-50

$\mathrm{H} 2-53$

26 Westinghouse Hanford Company

D. W. Bergmann

R3-86

T. D. Cooper

T5-12

R. G. Cowen

C. DeFigh-Price

R3-86

X3-79

D. R. Duncan

J. C. Fulton

R3-86

R3-11
No. of

Copies

E. W. Gerber

R3-86

L. H. Goldman

R3-86

V. L. Hoefer

H0-38

L. A. Lawrence

L5-01

B. J. Makenas

L5-01

J. D. Mathews

X3-61

C. R. Miska

R3-86

R. P. Omberg

R3-86

A. L. Pitner (5)

L5-01

S. P. Roblyer

H0-38

J. P. Schmidt

X3-78

P. K. Shen

R3-87

D. J. Trimble

L5-01

J. C. Wiborg

R3-86

Central Files

A3-88

OSTI

MAC Technical Services Company

R. P. Denise

R3-82

22 Pacific Northwest National Laboratory

J. Abrefah

P7-14

A. L. Doherty

K8-34

E. R. Gilbert

K8-34

M. L. Gore

K7-94

A. B. Johnson, Jr. (10)

K8-34

P. A. Scott

R3-87

S. M. Short

R3-85

Publishing Coordination

K1-06

Technical Report Files (5)

2. SAIC

M. M. Beary

H0-50

P. C. Owczarski

HO-50 
3 Technical Advisory Group

R. G. Ballinger

J. C. Devine

S7-41

R. F. Williams

S7-41

S7-41

Distr.2 